\title{
GAMBARAN SINDROMA PRAHAID PADA REMAJA
}

\author{
${ }^{1}$ Septa Ayu Bungasari \\ ${ }^{2}$ Hermie M. M. Tendean \\ ${ }^{2}$ Eddy Suparman
}

\author{
${ }^{1}$ Kandidat Skripsi Fakultas Kedokteran Universitas Sam Ratulangi \\ ${ }^{2}$ Bagian Obstetri Ginekologi Fakultas Kedokteran Universitas Sam Ratulangi Manado \\ Email: ayubungasari@gmail.com
}

\begin{abstract}
Menstruation issue is a common gynecological issue experienced by adolescents. One of disorders linked with menstruation is premenstrual syndrome. According to ICD-10 issued by WHO, premenstrual syndrome included to gynecology disorder associated with female genital organs and menstrual cycle. Premenstrual syndrome can interfere with daily activities, interpersonal relationship, occupational achievement and educational performance due to impaired attention in class and absence from school.The research used survey descriptive method with questionnaire tool studied in 54 female students of the first semester in Faculty of Medicine, Sam Ratulangi University academic year of 2014-2015.Based on the research in 54 female students, the most respondents age was 18 years old $(48,1 \%)$, predominant types of symptom was psychology symptom in 54 samples $(100 \%)$, predominant psychology symptom was mood swing in 52 samples (96,3\%), predominant physical symptom was acne problem in 45 samples $(83,3 \%)$ and predominant behavioral symptom was argumentative in 17 samples (31,5\%).
\end{abstract}

Keywords: premenstrual, syndrome, adolescent, teenage

\begin{abstract}
Abstrak: Masalah yang timbul pada haid merupakan masalah ginekologi yang sering dikeluhkan remaja. Salah satu gangguan yang berhubungan dengan haid adalah sindroma prahaid.Menurut ICD ke-10 yang dikeluarkan WHO, sindroma prahaid tercantum sebagai kelainan ginekologi yang terkait dengan organ kelamin wanita dan siklus haid.Kumpulan gejala yang dirasakan menjelang haid mengganggu aktivitas sehari - hari, hubungan interpersonal, hasil kerja dan prestasi akademik karena kurang perhatian dalam kelas dan sering tidak hadir.Penelitian ini menggunakan metode survei deskriptif dengan alat kuesioner yang dilakukan pada 54 mahasiswi semester 1 Fakultas Kedokteran Unsrat tahun ajaran 20142015.Berdasarkan penelitian pada 54 mahasiswi, didapatkan distribusi umur responden terbanyak adalah 18 tahun (48,1\%), jenis gejala yang paling dominan muncul adalah gejala psikologis sebanyak 54 orang (100\%), gejala psikologis terbanyak adalah perubahan mood sebanyak 52 orang (96,3\%), gejala fisik terbanyak adalah timbul jerawat sebanyak 45 orang $(83,3 \%)$ dan gejala perilaku terbanyak adalah suka menentang sebanyak 17 orang (31,5\%).
\end{abstract}

Kata kunci: prahaid, sindroma, remaja

Remaja adalah periode pertumbuhan dan perkembangan yang terjadi setelah masa kanak - kanak dan sebelum masa dewasa. ${ }^{1}$ Masa remaja merupakan masa peralihan yang ditandai dengan percepatan perkembangan fisik, mental, emosional, dan sosial. ${ }^{2}$ Batasan remaja menurut
WHOdan BKKBNyaitu umur 10 - 19 tahun. ${ }^{1,3}$ Selama periode reproduksi kehidupan, seorang wanita akan mengalami haid atau menstruasi. ${ }^{4}$ Haid adalah perdarahan vagina periodik yang terjadi dengan terlepasnya mukosa rahim. ${ }^{5}$ Masalah yang timbul pada haid merupakan 
masalah ginekologi yang sering dikeluhkan pada remaja. ${ }^{6}$ Salah satu gangguan yang berhubungan dengan haid adalah sindroma prahaid.Sindroma prahaid merupakan kumpulan keluhan yang biasanya ditemukan 7 - 10 hari menjelang haid. ${ }^{7}$ Menurut International Classification of Diseases (ICD)10 yang dikeluarkan WHO, sindroma prahaid tercantum sebagai kelainan ginekologi yang terkait dengan organ kelamin wanita dan siklus haid. ${ }^{8}$ Gejala - gejala sindroma prahaid terdiri dari gejala emosional, gejala fisik dan gejala perilaku serta dapat bervariasi berdasarkan intensitas. ${ }^{9}$ Keluhan yang muncul di antaranya adalah cemas, lelah, susah konsentrasi, susah tidur, hilang energi, nyeri kepala, nyeri perut dan nyeri pada payudara. ${ }^{7}$ Sindroma prahaid memiliki tingkat morbiditas tinggi dan mengurangi kualitas hidup usia reproduksi. ${ }^{9}$ Walaupun sindroma prahaid tidak mengancam nyawa, namun dapat memengaruhi produktivitas dan kesehatan mental seorang wanita.Seedhom et al menemukan 203 (80,2\%) dari 253 mahasiswi di Mesir mengeluh sindroma prahaid. Dalam penelitiannya, terdapat prevalensi gejala sindroma prahaid berat yaitu sangat lemah $(34,8 \%)$, perubahan suasana hati $(28,9 \%)$, cemas (24,1\%), mudah marah (21,7\%) dan nyeri tungkai (19\%). ${ }^{10}$ Berdasarkan penelitian Kamat et al, terdapat 220 dari 492 wanita meminta pertolongan dokter untuk mengurangi sindroma yang dirasakan menjelang haid. ${ }^{11}$ Di Indonesia, Sianipar et al meneliti sindroma prahaid pada siswi SMA di Jakarta Timur dan prevalensi yang didapatkan sebesar $75,8 \%{ }^{12}$

\section{METODE PENELITIAN}

Penelitian ini menggunakan metode survei deskriptif dengan alat kuesioner.Subjek penelitian adalah seluruh mahasiswi semester 1 Fakultas Kedokteran Unsrat Manado tahun akademik 2014 2015 yang berjumlah 54 orang.Penelitian ini dilakukan sejak bulan Oktober 2014 hingga bulan November 2014 bertempat di ruang kuliah Fakultas Kedokteran Unsrat.Variabel penelitian adalah gejala fisik, gejala psikologis dan gejala perilaku.

\section{HASIL PENELITIAN}

Berdasarkan penelitian yang telah dilakukan pada 54 mahasiswi semester 1 Fakultas Kedokteran Unsrat Manado periode Oktober - November 2014, maka diperoleh data sebagai berikut.

Tabel 1. Karakteristik Umur Sampel

\begin{tabular}{ccc}
\hline Umur (tahun) & Jumlah & $\mathbf{\%}$ \\
\hline 16 & 2 & 3,7 \\
17 & 25 & 46,3 \\
18 & 26 & 48,1 \\
19 & 1 & 1,9 \\
\hline Total & $\mathbf{5 4}$ & $\mathbf{1 0 0}$ \\
\hline
\end{tabular}

Tabel 2.Distribusi Berdasarkan Jenis Gejala Sindroma Prahaid

\begin{tabular}{lcccc}
\hline \multirow{2}{*}{ Sindrom prahaid } & \multicolumn{2}{c}{ Tidak } & \multicolumn{2}{c}{ Ya } \\
\cline { 2 - 5 } & Jumlah & $\%$ & Jumlah & $\%$ \\
\hline Gejala fisik & 4 & 7,4 & 50 & 92,6 \\
Gejala psikologis & 0 & 0 & 54 & 100 \\
Gejala perilaku & 24 & 44,4 & 30 & 55,6 \\
\hline
\end{tabular}




\section{BAHASAN}

Dari hasil penelitian dengan menggunakan alat kuesioner yang dibagikan secara keseluruhan pada 54 orang sampel yang merupakan mahasiswi semester 1 Fakultas Kedokteran Unsrat, maka diperoleh hasil sebagai berikut.
Karakteristik umur sampel yang diperoleh dari penelitian sesuai gambaran pada tabel 1 , dimana umur yang terbanyak adalah 18 tahun berjumlah 26 orang atau sekitar 48,1 \% diikuti dengan umur 17 tahun yang berjumlah 25 orang atau sekitar $46,3 \%$.

Tabel 3.Distribusi Berdasarkan Gejala Fisik

\begin{tabular}{lcccc}
\hline \multirow{2}{*}{ Gejala fisik } & \multicolumn{2}{c}{ Tidak } & \multicolumn{2}{c}{ Ya } \\
\cline { 2 - 5 } \multicolumn{1}{c}{ Jumlah } & $\%$ & Jumlah & $\%$ \\
\hline Rasa lelah / lemah & 15 & 27,8 & 39 & 72,2 \\
Perut kembung & 38 & 70,3 & 16 & 29,7 \\
Nyeri/bengkak payudara & 39 & 72,2 & 15 & 27,8 \\
Timbul jerawat & 9 & 16,7 & 45 & 83,3 \\
Nafsu makan meningkat & 22 & 40,8 & 32 & 59,2 \\
Sakit kepala & 28 & 51,9 & 26 & 48,1 \\
Nyeri sendi & 38 & 70,3 & 16 & 29,7 \\
Nyeri otot & 33 & 61,1 & 21 & 38,9 \\
\hline
\end{tabular}

Tabel 4.Distribusi Berdasarkan Gejala Psikologis

\begin{tabular}{lcccc}
\hline \multirow{2}{*}{ Gejala Psikologis } & \multicolumn{2}{c}{ Tidak } & \multicolumn{2}{c}{ Ya } \\
\cline { 2 - 5 } & Jumlah & $\%$ & Jumlah & $\%$ \\
\hline Rasa cemas & 17 & 31,5 & 37 & 68,5 \\
Mudah tersinggung & 15 & 27,8 & 39 & 72,2 \\
Tegang & 25 & 46,3 & 29 & 53,7 \\
Perubahan mood & 2 & 3,7 & 52 & 96,3 \\
Mudah marah & 7 & 12,9 & 47 & 87,1 \\
\hline
\end{tabular}

Tabel 5.Distribusi Berdasarkan Gejala Perilaku

\begin{tabular}{lcrcc}
\hline \multirow{2}{*}{ Gejala Perilaku } & \multicolumn{2}{c}{ Tidak } & \multicolumn{2}{c}{ Ya } \\
\cline { 2 - 5 } \multicolumn{1}{c}{ Jumlah } & $\%$ & Jumlah & $\%$ \\
\hline Menarik diri dari pergaulan & 48 & 88,9 & 6 & 11,1 \\
Suka menentang/berdebat & 37 & 68,5 & 17 & 31,5 \\
Suka menyendiri & 39 & 72,2 & 15 & 27,8 \\
Menangis & 45 & 83,3 & 9 & 16,7
\end{tabular}

\footnotetext{
Batasan umur 16 tahun sebanyak 2 orang atau sekitar 3,7 \% dan sisanya 1 orang berumur 19 tahun atau hanya sekitar 1, 9\%. Total sampel yang diperoleh memenuhi batasan remaja WHOdan BKKBN yaitu umur $10-19$ tahun. ${ }^{1,3}$

Tabel 2 menerangkan distribusi berdasarkan jenis gejala sindroma prahaid yang dibagi atas gejala fisik, psikologis

dan perilaku.Hasil penelitian yang dilakukan pada 54 orang mahasiswi menggambarkan gejala terbanyak adalah gejala psikologis yang ditemukan pada seluruh sampel atau sekitar $100 \%$. Kemudian yang mengalami gejala fisik berjumlah 50 orang atau sekitar 92,6\% dan gejala perilaku berjumlah 30 orang atau sekitar 55,6 \%. Yonkers et al menyatakan gejala psikologis merupakan
} 
kunci utama sindroma prahaid, mekanisme dasarnya melibatkan otak. Steroid gonad mudah melewati sawar darah otak, reseptornya juga berlimpah di bagian otak yang mengatur emosi dan perilaku, termasuk amigdala dan hipotalamus. ${ }^{13}$ Pawestri menemukan gejala psikologis sebanyak 58,3 \%, gejala fisik sebanyak 38,5 \% dan gejala perilaku sebanyak $27,4 \%{ }^{14}$

Tabel 3 menjelaskan distribusi berdasarkan gejala fisik yang terdiri atas 8 variabel, dimana yang terbanyak yaitu timbul jerawat sebanyak 45 orang $(83,3$ $\%)$ diikuti rasa lemah 39 orang (72,2 \%), nafsu makan meningkat 32 orang (59,2 $\%$ ), sakit kepala 26 orang (48,1\%), nyeri otot 21 orang (38,9\%), nyeri sendi 16 orang $(29,7 \%)$, perut kembung 16 orang $(29,7 \%)$ dan nyeri payudara 15 orang (27,8\%).

Faktor hormonal cukup berperan dalam timbulnya gejala saat menjelang haid. Kelebihan estrogen dapat meningkatkan prolaktin yang menimbulkan nyeri payudara dan meningkatkan aldosteron yang berperan pada naiknya kadar sodium dan retensi air yang mengakibatkan tegang pada payudara. ${ }^{15}$ Dalam sebuah penelitian, 63 $\%$ wanita mengalami peningkatan $25 \%$ dalam jumlah lesi inflamasi atau jerawat yang terkait dengan prahaid. ${ }^{16}$ Perubahan hormon dapat menyebabkan kelenjar sebasea memroduksi lebih banyak sebum. Zat berminyak ini dapat menyumbat poripori dan menyebabkan timbulnya lesi jerawat. ${ }^{17}$ Wanita yang mengalami sindroma prahaid memiliki kadar leptin yang tinggi selama siklus haid. Mereka cenderung makan makanan yang mengandung tinggi lemak, tinggi gula dan rendah protein. Perubahan neurotransmiter dan interaksinya dengan hormon dapat mengakibatkan terjadinya berat badan lebih dan obesitas. ${ }^{18}$

Tabel 4 menunjukkan distribusi gejala psikologis yang terdiri atas 5 variabel terbanyak, di antaranya adalah perubahan mood / suasana hati 52 orang (96,3 \%) kemudian mudah marah 47 orang (87, $1 \%)$, mudah tersinggung 39 orang $(72,2 \%)$, rasa cemas sebanyak 37 orang $(68,5 \%)$ dan tegang 29 orang $(53,7$ $\%)$.

Perubahan kadar hormon estrogen memengaruhi neurotransmiter yang bekerja sentral yaitu serotonin. ${ }^{19,20}$ Menurut Meschino, kurangnya neurotransmisi serotonergik mengakibatkan suasana hati depresi, iritabilitas, agresi, kontrol impuls yang buruk.Peningkatan rasio estrogen progesteron terkait dengan penurunan endorfin di otak sehingga menyebabkan perubahan suasana hati. ${ }^{15}$

Tabel 5 memaparkan distribusi gejala perilaku yang terdiri atas 4 variabel yakni suka menentang sebanyak 17 orang atau sekitar 31,5 \%, suka menyendiri sebanyak 15 orang atau sekitar 27,8 \%, menangis sebanyak 9 orang atau sekitar 16,7 \% dan menarik diri dari pergaulan yang dialami 6 orang atau sekitar $11,1 \%$.

Seedhom mendapatkan sebanyak 49 orang atau sekitar 19,4 \% mengalami gejala menangis saat prahaid. ${ }^{10}$ Gejala perilaku juga berasosiasi dengan faktor hormonal seperti halnya gejala psikologis yang melibatkan neurotransmiter otak yaitu serotonin. ${ }^{13}$ Pada wanita yang mengalami sindroma prahaid terjadi ketidakseimbangan hormon estrogen dan progesteron, dimana kadar estrogen meningkat dan kadar progesteron menurun sehingga terjadi penurunan sintesis serotonin yang berpengaruh pada perubahan suasana hati dan perilaku. ${ }^{18}$

\section{SIMPULAN}

Pada penelitian ini dapat disimpulkan bahwa gambaran sindroma prahaid pada remaja yang paling dominan menurut jenis gejala adalah gejala psikologis. Gejala psikologis prahaid terbanyak yaitu perubahan suasana hati.Gejala fisik prahaid terbanyak yaitu timbul jerawat, serta gejala perilaku prahaid terbanyak yaitu suka menentang atau berdebat.

\section{SARAN}

Para remaja dapat meningkatkan pengetahuan mengenai sindroma prahaid 
sehingga dapat mengetahui cara mengatasi gejala dengan aman dan tepat.Untuk peneliti selanjutnya diharapkan dapat meneliti tentang hubungan penyebab atau faktor risiko dan gejala prahaid pada remaja.

\section{UCAPAN TERIMA KASIH}

Penulis mengucapkan terima kasih kepada semua pihak yang turut serta menyumbang pikiran dalam penulisan artikel ini.

\section{DAFTAR PUSTAKA}

1. World Health Organization. Maternal, newborn, child and adolescent health. [diunduh 9 September 2014]. Tersedia dari:

http://www.who.int/maternal_child_ad olescent/topics/adolescence/dev/en/

2. Dhamayanti M. Overview adolescent health problems and services. 10 September 2013. [diunduh 9 September 2014]. Tersedia dari: http://idai.or.id/publicarticles/seputar-kesehatananak/overview-adolescent-healthproblems-and-services.html

3. Pitoyo AJ, Lestariningsih SP, Kiswanto E. Ayo menjadi remaja berkarakter : religius, sehat, cerdas, produktif. Lestariningsih SP, Gamayanti P, Fauziah S, ilustrator. Hasmi E, editor. Jakarta: Direktorat Kerjasama Pendidikan Kependudukan BKKBN; 2013. p. 6.

4. Sembulingam K, Sembulingam P. Buku ajar fisiologi kedokteran. Edisi Ke5.Hartono A, translator. Herman RB, editor. Tangerang: Binarupa Aksara Publisher; 2013. p. 523.

5. Ganong WF. Buku ajar fisiologi kedokteran.Edisi ke-22. Pendit BU, translator. Novrianti A, editor. Jakarta: EGC; 2008 p. 451-4.

6. Lestari H, Metusala J, Suryanto DY. Gambaran dismenorea pada remaja putri sekolah menengah pertama di manado. Sari Pediatri. 2010;12:100.

7. Hendarto H. Gangguan haid / perdarahan uterus abnormal. Dalam: Anwar $\mathrm{M}$, Baziad A, Prabowo P, editors. Ilmu kandungan.Edisi ke-3. Jakarta: Bina Pustaka Sarwono Prawirohardjo; 2011 p. 162, 183.
8. World Health Organization. International statistical classification of diseases and related health problems 10th revision. [diunduh 10 September 2014]. Tersedia dari:

http://apps.who.int/classifications/icd10 /browse/2010/en\#/N80-N98

9. Zaka M, Mahmood KT. Pre-menstrual syndrome - a review. Journal of Pharmaceutical Sciences and Research. 2012;4:1685-89.

10. Seedhom AE, Mohammed ES, Mahfouz EM. Life style factors associated with premenstrual syndrome among el-minia university students, Egypt. ISRN Public Health. 2013;2013:2.

11. Kamat SV, Nimbalkar AS, Nimbalkar SM. Premenstrual syndrome in adolescents of anand - cross sectional study from india using premenstrual symptoms screening tool for adolescents. Arch Dis Child. 2012;97:136.

12. Sianipar O, Bunawan NC, Almazini P, Calista N, Wulandari P, Rovenska N, et al. Prevalensi gangguan menstruasi dan faktor-faktor yang berhubungan pada siswi smu di kecamatan pulo gadung jakarta timur. Maj Kedokt Indon. 2009;59:311.

13. Yonkers KA, O'Brien PM, Eriksson E. Premenstrual syndrome. NIH Public Access Author Manuscript. 2008;4-5.

14.Pawestri DR. Gambaran tanda dan gejala pre menstrual syndrome pada remaja putri di SMKN 9 Surakarta. 2014;53.

15. Meschino JP. Premenstrual syndrome: the role of nutrition, supplementation and chiropractic in pms management. Dynamic Chiropractic. 2002;20:2.

16. Kim GK, Del Rosso J. Oral Spironolactone in post-teenage female patients with acne vulgaris.J Clin Aesthet Dermatol. 2012;4.

17.Johnson TA. Visual Guide to Premenstrual $\begin{array}{llll}\text { Syndrome } & \text { (PMS). } & \text { [diunduh } 8\end{array}$ Desember 2014]. Tersedia dari: http://www.webmd.com/women/pms/ss /slideshow-premenstrual-syndromepms

18.Putri RP. Hubungan antara derajat sindrom pramenstruasi dan aktivitas fisik dengan perilaku makan pada remaja putri. 2013;13.

19.Perez-Lopez FR, Chedraui P, PerezRoncero G, Lopez-Baena MT, Cuadroz-Lopez JL. Premenstrual 
Bungasari, Tendean, Suparman: Gambaran Sindroma Prahaid...

syndrome and premenstrual dysphoric disorder: symptoms and cluster influences. The Open Psychiatry Journal. 2009;3:41,44.

20.Dickerson LM, Mazyck PJ, Hunter MH. Premenstrual syndrome. Am Fam Physician. 2003;67:1743-45. 